\title{
Integrating microRNAs into the complexity of gonadotropin signaling networks
}

\section{Kelly León ${ }^{1}$, Nathalie Gallay ${ }^{1}$, Anne Poupon ${ }^{1}$, Eric Reiter ${ }^{1}$, Rozenn Dalbies-Tran ${ }^{2}$ and Pascale Crepieux ${ }^{1 *}$}

BIOS Group, INRA, UMR85, Unité Physiologie de la Reproduction et des Comportements, Nouzilly, France; CNRS, UMR7247, Nouzilly, France; Université François Rabelais, Tours, France

2 BINGO Group, INRA, UMR85, Unité Physiologie de la Reproduction et des Comportements, Nouzilly, France; CNRS, UMR7247, Nouzilly, France; Université

François Rabelais, Tours, France

\section{Edited by:}

Gaetano Santulli, Columbia

University, USA

Reviewed by:

Gaetano Santulli, Columbia

University, USA

Kristine Hardy, University of

Canberra, Australia

Peter Stanton, Prince Henry's

Institute of Medical Research,

Australia

*Correspondence:

Pascale Crepieux, BIOS Group,

UMR 7247, Unité Physiologie

de la Reproduction et des

Comportements, 37380 Nouzilly,

France

e-mail:pascale.crepieux@

tours.inra.fr
Follicle-stimulating hormone (FSH) is a master endocrine regulator of mammalian reproductive functions. Hence, it is used to stimulate folliculogenesis in assisted reproductive technologies (ART), both in women and in breeding animals. However, the side effects that hormone administration induces in some instances jeopardize the success of ART. Similarly, the luteinizing hormone (LH) is also of paramount importance in the reproductive function because it regulates steroidogenesis and the $\mathrm{LH}$ surge is a pre-requisite to ovulation. Gaining knowledge as extensive as possible on gonadotropin-induced biological responses could certainly lead to precise selection of their effects in vivo by the use of selective agonists at the hormone receptors. Hence, over the years, numerous groups have contributed to decipher the cellular events induced by FSH and $\mathrm{LH}$ in their gonadal target cells. Although little is known on the effect of gonadotropins on microRNA expression so far, recent data have highlighted that a microRNA regulatory network is likely to superimpose on the signaling protein network. No doubt that this will dramatically alter our current understanding of the gonadotropin-induced signaling networks. This is the topic of this review to present this additional level of complexity within the gonadotropin signaling network, in the context of recent findings on the microRNA machinery in the gonad.

Keywords: gonadotropins, microRNAs, G protein-coupled receptors, signaling networks, Sertoli cells, granulosa cells

\section{INTRODUCTION}

The role of the gonadotropins, Follicle-stimulating hormone (FSH) and luteinizing hormone ( $\mathrm{LH})$, in the control of reproductive function in Mammals is widely acknowledged, hence the use of their recombinant or purified surrogates to complement fertility defects in women, and to synchronize ovulation in breeding animals. The gonadotropin-induced signaling pathways have been the matter of extensive investigations, in part because a more precise knowledge of their action within the cell could help avoiding some unwanted side effects caused by their in vivo administration. To induce complex signaling networks leading to integrated biological responses, gonadotropins interact with their cognate G protein-coupled receptors (GPCR), expressed at the surface of somatic cells within the male and female gonad. Whereas the transcriptome alteration induced by FSH in the male and female gonad has been analyzed (McLean et al., 2002; Sasson et al., 2003; Sadate-Ngatchou et al., 2004; Meachem et al., 2005; Perlman et al., 2006), as well as the post-translational modifications of signaling effectors (Gloaguen et al., 2011), the role of post-transcriptional regulations and their putative implication in gonadotropin-induced signaling network have been underappreciated to date. Notably, the role of microRNA in regulating cell signaling induced by FSH and LH now appears as an emerging field in the control of reproductive function, at the molecular level. As microRNAs are thought to constitute a bona fide network, intertwined with cell signaling pathways, it is now of great interest to discuss the role that those microRNAs could potentially play in regulating gonadotropin-induced signaling within their natural target cells in the gonad. How these microRNA networks might regulate the compartmentalization of gonadotropin signaling components and might control the reaction rates of these signaling biochemical reactions will be discussed.

\section{MicroRNAs FROM THE MOLECULE TO THE NETWORK}

The discovery of the first microRNA, C. elegans Lin-4, in 1993 (Lee et al., 1993; Wightman et al., 1993) has profoundly revolutionized our perception and understanding of gene regulation. At that time, small antisense RNA were tedious to identify by standard genetic approaches, but, since then, the use of nextgeneration sequencing and its ongoing technological improvements has pervaded the benches, leading to the identification of 1872 mature microRNAs in human, 1186 in mouse and 449 in rat, according to the Mirbase database (www.mirbase.org, release 20, June 2013).

MicroRNAs are endogenous $\simeq 22$-nucleotide long, non-coding RNAs that regulate gene expression post-transcriptionally, upon specific base-pairing of their $5^{\prime}$ (the seed) generally to the $3^{\prime}$ untranslated region (UTR) of a target mRNA. They are thought 
to act primarily (about $80 \%$ ) by destabilizing cytoplasmic mRNA (Guo et al., 2010). However, they can also regulate mRNA translation, and it has been proposed that the effect of microRNA complexes on translation oscillates between an inhibitory and a stimulating action during the cell cycle in actively cycling cells like Human Embryonic Kidney (HEK) 293 cells (Vasudevan et al., 2007). Interestingly, during physiological differentiation processes, microRNAs are considered to support mRNA cellspecificity (Farh et al., 2005; Sood et al., 2006), and overall, it is now admitted that they confer robustness to gene regulation (Cui et al., 2006; Tsang et al., 2007; Lin et al., 2013). To regulate cell fate, they exert diverse actions on signaling networks: positive feedback loops, mutual negative feedback loops, or combining positive and negative feedbacks (Figure 1) (Tsang et al., 2007).

Functional approaches by knocking-out microRNA-encoding genes have proven limited potential. That is, functional redundancy of microRNA with shared seed sequences has precluded the observation of an obvious phenotype by gene knockout of individual microRNA. Even knocking-out an entire family of microRNA sharing the same seed might be inconclusive, given that mismatches between microRNA and target are tolerated. Alternatively, the enzymes that tune microRNA processing have been knocked-out in mouse (Table 1). Consistent with a key role of microRNAs in cell-lineage decision-making, knockout of the Dicer gene that encodes an RNase III processing the maturation of both microRNA and endogenous short-interfering RNA, is embryonic lethal at E7.5 (Bernstein et al., 2003), similarly to knock-out of the gene encoding DiGeorge Syndrome critical region gene 8 (DGCR8) or the DGCR8 co-factor, Argonaute 2 (AGO2) (Morita et al., 2007; Wang et al., 2007).

\section{MicroRNAs IN THE GONAD: 10 YEARS AFTER}

In 2004, low-density human microRNA chips (Barad et al., 2004; Liu et al., 2004) have been designed and thereafter, 29 microRNAs from adult mouse testes were cloned. These seminal experiments settled the foundation for a role of microRNAs in regulating gonadal functions. By DNA electroporation of fluorescent reporter genes in vivo, it was elegantly demonstrated that RNA interference is active during the whole spermatogenetic process (Shoji et al., 2005), a finding further supported by high-throughput microarray analyses of microRNAs in immature vs. mature mouse whole testes (Yan et al., 2007). Later on, microRNAs were directly cloned from purified populations of spermatogenic cells (Ro et al., 2007a) and from the ovary (Ro et al., 2007b). A prominent feature of male post-meiotic, haploid germ cells is the chromatoid body, a perinuclear structure enriched in components of RNA interference silencing complex (miRISC), such as microRNAs, Dicer, Argonaute proteins and the mouse Vasa homolog (MVH) RNA helicase (Kotaja et al., 2006). This is relevant to the observation that compaction of chromatin that takes place in haploid germ cells precludes transcription, so that post-transcriptional regulation mainly occurs (Tanaka and Baba, 2005). The relative expression level of these components in pachytene spermatocytes, in round spermatids and in elongated spermatids suggests a programmed, stagespecific involvement of the different elements of the RNA interference machinery in spermatogenesis (Gonzalez-Gonzalez et al., 2008a). When the Dicer gene has been knocked-out specifically with tissue-nonspecific alkaline phosphatase (TNAP)-driven Cre recombination, spermatogenic defects were detected prior to meiosis (Hayashi et al., 2008; Maatouk et al., 2008), which seemed to be independent of AGO2 activity (Hayashi et al., 2008) (Table 1). However, in these models, the primary defects occurred in primordial germ cells (PGC), which is too early in development to figure out clearly the bases of the spermatogenesis defects observed in the adult. Therefore, Dicer has also been deleted in germ cells with Cre recombinase being expressed in late development (Papaioannou et al., 2009; Romero et al., 2011) and in the neonatal life (Korhonen et al., 2011; Wu et al., 2012). In these mice, the observed phenotype was consistently a defect in spermiogenesis leading to depletion in haploid cells.

Although they are endowed with microRNA-independent functions (Johanson et al., 2013), Dicer and Drosha are renowned for their implication in microRNA biogenesis. Whereas Dicer is involved in the biogenesis of both endogenous short-interfering RNAs (siRNAs) and microRNAs, the Drosha RNase III is amenable for microRNA biogenesis solely (Lee et al., 2003), and its gene has also been conditionally knocked-out in germ cells (Wu et al., 2012). The resulting phenotype is a severe impairment of the haploid phases of spermatogenesis, as a result of meiotic defects (Table 1).

In comparison, in the developing oocyte, microRNA biogenesis appears suppressed. Dicer knockdown by synthetic siRNA as well as oocyte-restricted knockout of Dicer or Ago2 have shown that both genes are required for proper oocyte maturation before ovulation (Murchison et al., 2005; Kaneda et al., 2009; Mattiske et al., 2009; Liu et al., 2010). However, several lines of evidence have indicated that endogenous siRNAs and piwi-interacting RNAs (piRNAs), rather than microRNAs, are important for oocyte maturation and ovulation (Tam et al., 2008; Watanabe et al., 2008a,b; Ma et al., 2010; Suh et al., 2010). They include the moderate phenotype of mice with oocyte-restricted depletion of $D g c r 8$, the use of reporter constructs, and the profiling of small RNAs. Actually, efficiency of siRNAs in the oocyte has been very recently ascribed to an oocyte specific isoform of Dicer (Flemr et al., 2013). However, it cannot be excluded that microRNA could be synthesized during the earliest stages of oogenesis and stored for regulating gene expression later in the developing oocyte.

\section{MicroRNAs IN GONADAL SOMATIC CELLS}

The cellular targets of gonadotropins are somatic cells of the male and female gonad. Initially, model organisms have provided evidence for a role of microRNA in regulating somatic cell function. In Drosophila ovary and testis, the germline stem cells (GSCs) and somatic stem cells (SSCs) are housed together in a common niche. This niche provides signals that regulate GSC self-renewal and differentiation. The SSCs are non-dividing and enclose the GSC daughter cell that will ultimately give rise to sperm or eggs (Fuller and Spradling, 2007; Kirilly and Xie, 2007; Voog and Jones, 2010; de Cuevas and Matunis, 2011). Previous studies suggested the importance of microRNA biogenesis in the maintenance of ovarian stem cells. Mature microRNAs are generated from their 


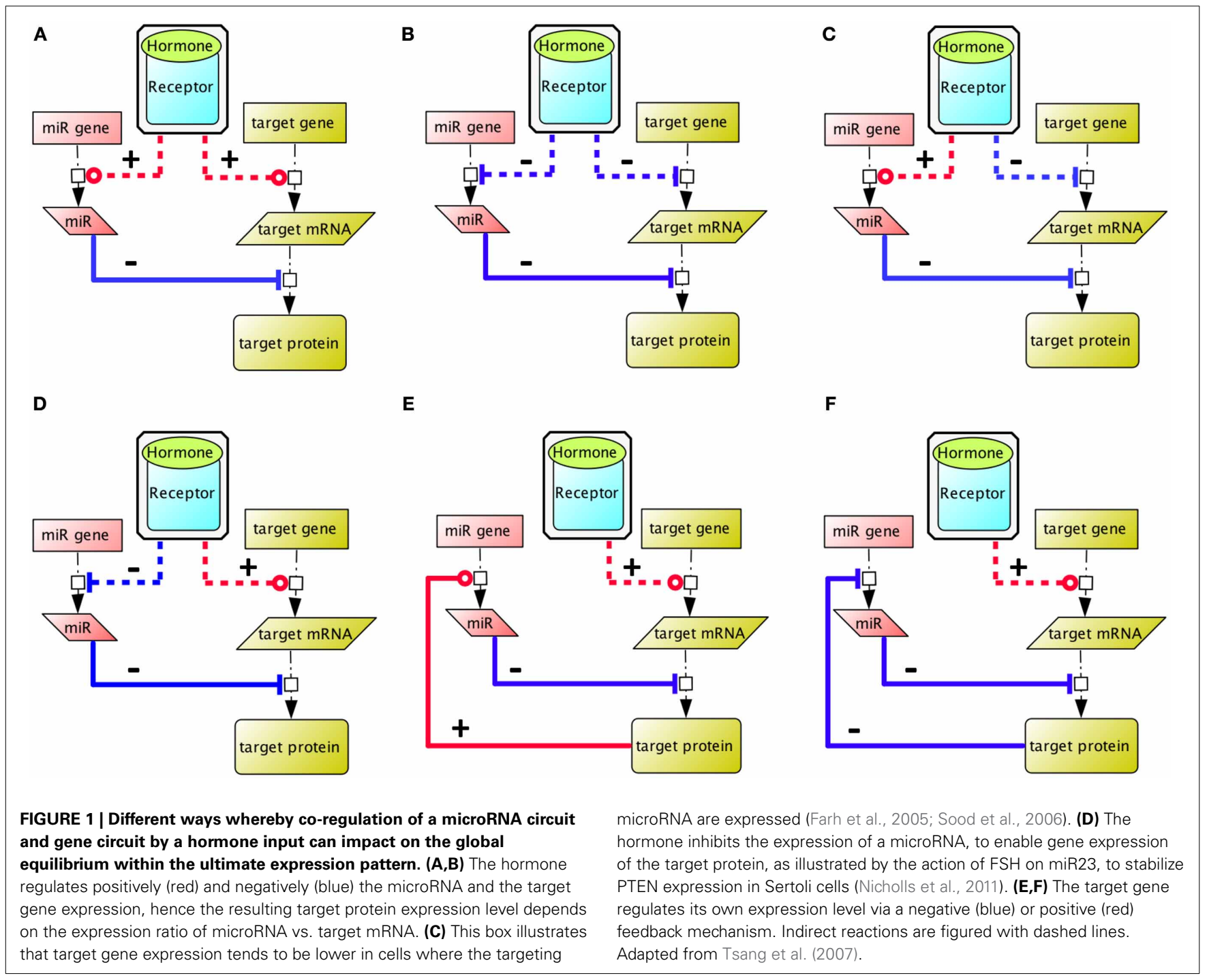

precursors by Dicer-1 (Dcr-1) (Lee et al., 2004) and the doublestranded RNA binding protein Loquacious (Loqs) (Forstemann et al., 2005). Dcr-1 is required for GSC and SSC maintenance in Drosophila ovary (Jin and Xie, 2007). Similarly, loqs mutants fail to maintain the self-renewal of GSCs (Forstemann et al., 2005). Argonaute 1 (AGO1) also plays an essential role in the maintenance of GSCs, since overexpression of Agol leads to GSC overproliferation, whereas loss of Ago1 results in the loss of GSCs (Yang et al., 2007).

In contrast to the ovary, the requirement for microRNA pathway components in the Drosophila testis has not been determined extensively. One example is provided by miR-7, a microRNA that could play a role in GSCs maintenance by targeting the 3' UTR of Bag-of-marbles (Bam) mRNA, which encodes a key differentiation factor (Pek et al., 2009). In addition, a novel microRNA-310/313 cluster has been identified as an antagonist of the Wingless (Drosophila Wnt) pathway. A crucial effector of this pathway is Armadillo (Arm), which is highly expressed in the hub cells that are in direct contact with the GSC and SSC in the testis (Yamashita et al., 2003). The microRNA-310/313 cluster can modulate Arm levels by directly targeting the $3^{\prime}$-UTRs of the Arm mRNA. Hence, as expected, microRNA-310/313-deficient flies cannot modulate Arm protein levels or activity and exhibit abnormal germ and somatic cell differentiation in the male gonad (Pancratov et al., 2013). Interestingly, the Wnt pathway is also very important in mammalian follicular development, since it fine-tunes the responsiveness to $\mathrm{LH}$ and FSH gonadotropins (Fan et al., 2010).

In Drosophila, the dependency of the niche on gonadotropinlike hormones is unlikely, and the only homolog hormones, Glycoprotein Hormone $\alpha 2$ (GPA2) and Glycoprotein Hormone $\beta 5$ (GPB5), have recently been proposed to be antidiuretic hormones, and probably not bona fide gonadotrope hormones (Sellami et al., 2011).

In Mammals, microRNAs have also been detected in mouse Sertoli cells (Gonzalez-Gonzalez et al., 2008b), in a structure resembling the nucleolus (Marcon et al., 2008). Their importance in gonadal physiology has been demonstrated by Sertoli cell-selective knock-out of the Dicer gene in mouse, which has unraveled the role of microRNA in supporting cell lineage of 
Table 1 | Phenotypic consequences of the depletion of genes involved in microRNA biogenesis in mouse.

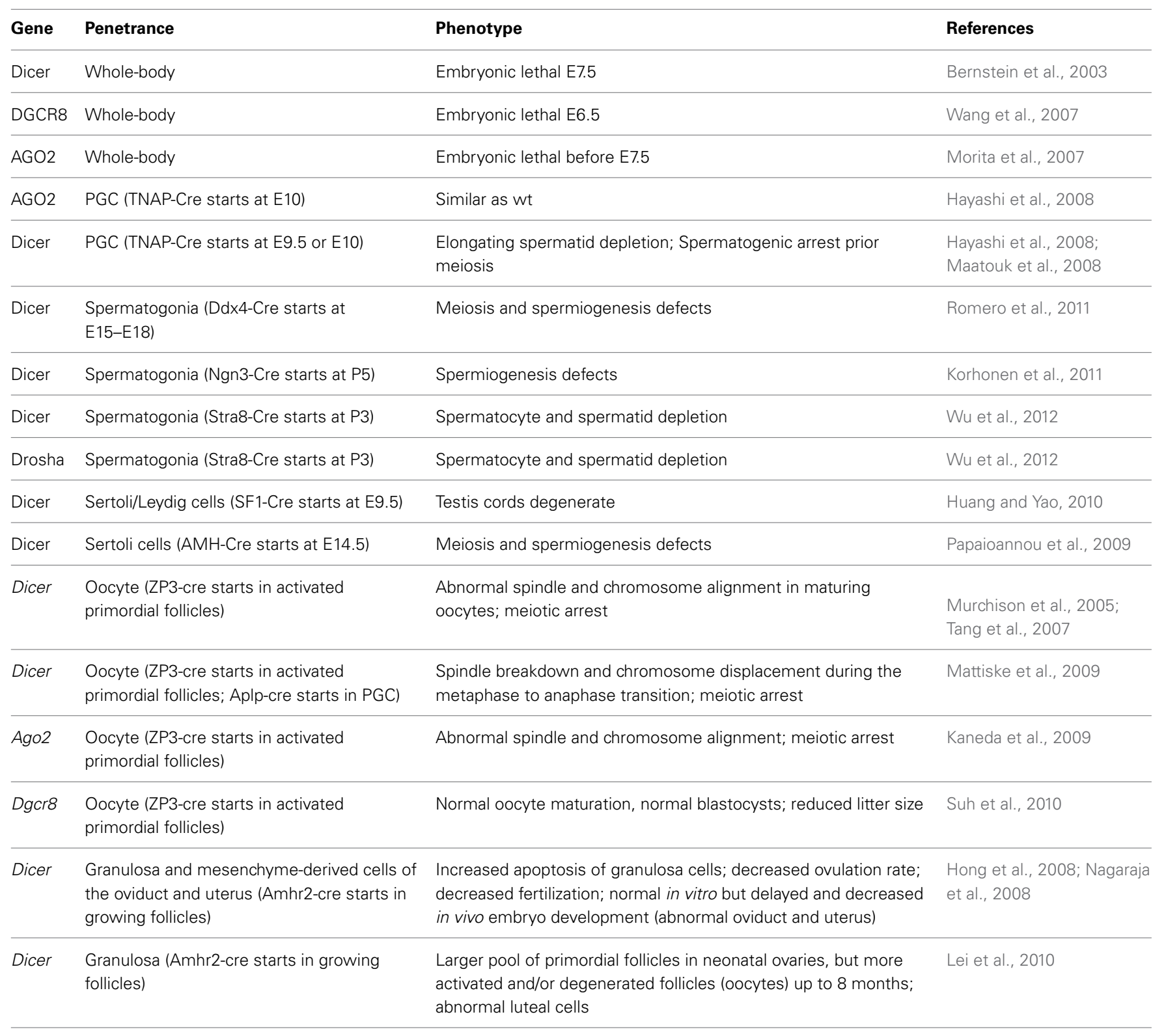

the testis, by regulating the expression of genes essential for meiosis and spermiogenesis (Papaioannou et al., 2009). Sertoli cell development itself was impaired as soon as P5, exhibiting major alterations of the testis proteome (Papaioannou et al., 2011). Consequently, Sertoli-cell restricted Dicer knocked-out mice are infertile. In addition, when achieved as early as E9.5, Sertoli/Leydig-cell specific disruption of Dicer severely compromises testis cord evolution (Huang and Yao, 2010). In the ovary, gonadotropins control the terminal phase of folliculogenesis starting when granulosa cells express the FSH receptor. Influence of canonical microRNA on ovarian function appears to be primarily through somatic cells. Indeed, selective disruption of Dicer expression in granulosa cells altered ovarian activity resulting in a decreased ovulation rate (Hong et al., 2008; Nagaraja et al., 2008; Gonzalez and Behringer, 2009; Lei et al., 2010). FSH affects the expression of a range of microRNA in cultured rat granulosa cells, with putative target genes involved in multiple signaling pathways (Yao et al., 2009, 2010). The challenge is now to identify the physiologically relevant targets.

\section{FSH SIGNALING PROPERTIES: THE BRIGHT SIDE OF THE MOON}

Before integrating microRNAs into the complexity of FSHinduced signaling network, here is a brief overview on how this signaling network is organized. In Mammals, FSH ability to alter gene transcription in granulosa and Sertoli cells has long been recognized (McLean et al., 2002; Sasson et al., 2003; SadateNgatchou et al., 2004; Meachem et al., 2005; Perlman et al., 2006). These effects are conveyed from the plasma membrane to the nucleus through the Gos/cAMP/protein kinase A (PKA) signaling 
cascade essentially (Means et al., 1974; Dattatreyamurty et al., 1987). More precisely, Gas-coupling leads to cAMP accumulation that in turn activates PKA (Zeleznik et al., 2003; EscamillaHernandez et al., 2008) and Exchange Protein directly Activated by cAMP (EPAC) (Gonzalez-Robayna et al., 2000; Wayne et al., 2007). Amongst other cytosolic targets, PKA has been reported to trigger p38 (Maizels et al., 1998), Extracellular signal-Regulated Kinases (ERK) 1,2 (Cottom et al., 2003) and p70 ribosomal S6 Kinase (p70S6K) (Lécureuil et al., 2005) whereas EPAC has been associated with p38 and Akt activation (Wayne et al., 2007; Choi et al., 2009). Gai-coupling counteracts cAMP accumulation but can also lead to ERK1,2 activation (Crépieux et al., 2001).

Over the last decade, this picture has become considerably more complex as activated the FSH receptor (FSHR) has been reported to couple to multiple other transduction mechanisms ultimately leading to the activation of an intricate intracellular network (Gloaguen et al., 2011; Ulloa-Aguirre et al., 2011). Importantly, this FSH-induced signaling network is now perceived as regulating protein translation (Musnier et al., 2010, 2012) and as controlling the fate of FSH-targeted cells (Loss et al., 2007; Richards and Pangas, 2010) in addition to its effects at the level of gene transcription.

Several Gas-independent mechanisms capable of functionally coupling the FSHR with intracellular signaling cascades have been reported to physically and/or functionally interact with the FSHR and to trigger downstream signaling events (Zeleznik et al., 2003; Escamilla-Hernandez et al., 2008; Gloaguen et al., 2011). These mechanisms involve Gai (Arey et al., 1997; Crépieux et al., 2001), $\beta$-arrestins (Kara et al., 2006; Wehbi et al., 2010a,b; Tranchant et al., 2011), Epithelial Growth Factor Receptor (EGFR) (Cottom et al., 2003; Andric and Ascoli, 2006; Yang and Roy, 2006; Wayne et al., 2007) and Adaptor protein, phosphotyrosine interaction, $\mathrm{PH}$ domain and leucine zipper containing 1 (APPL1) (Nechamen et al., 2004, 2007; Thomas et al., 2011). Although the coupling mechanisms that promote Phosphoinositide 3-kinase (PI3K) (Zeleznik et al., 2003) and Phosphatase and Tensin homolog deleted on chromosome 10 (PTEN) (Dupont et al., 2010) activation upon FSH exposure are as yet unidentified, APPL1 is a likely candidate because it has been reported to trigger downstream signaling through PI3K (Nechamen et al., 2004). Besides, the interaction between APPL1 and the FSHR has been shown to be necessary for the activation of inositolphosphate/calcium pathways upon FSH exposure (Thomas et al., 2011) of the KGN granulosa cell line. All of these coupling mechanisms subsequently connect to second messenger-activated effectors and/or to downstream signaling cascades.

Like most GPCRs, the activated FSHR has been shown to specifically interact with $G$ protein-coupled receptor kinases (GRKs) and with $\beta$-arrestins (Reiter and Lefkowitz, 2006). Initially, these proteins have been related to the control of desensitization, internalization and recycling of the receptor but, more recently, $\beta$-arrestins have been shown to act as $G$ proteinindependent signal transducers at the FSHR, leading to the activation of ERK1,2 and rpS6, in heterologous cell lines (Kara et al., 2006; Wehbi et al., 2010a,b; Tranchant et al., 2011). More generally, they enable post-translational modifications of a wide array of intracellular targets (Xiao et al., 2010), by acting as multifunctional scaffolds of multiple protein partners (Xiao et al., 2007). Hence, $\beta$-arrestins are likely involved in the activation of numerous other signaling pathways at the FSHR, in FSH natural target cells, although this remains to be demonstrated experimentally.

Transduction of FSH signal within granulosa cells also leads to transactivation of the epithelial growth factor receptor, by autophosphorylation of the EGFR (Cottom et al., 2003; Wayne et al., 2007; Zhang et al., 2007). In addition, when the EGFR is inhibited, a decrease in the ability of FSH to induce ERK and Cyclin-dependent kinase (CDK) 4 activation (Cottom et al., 2003; Andric and Ascoli, 2006; Yang and Roy, 2006; Wayne et al., 2007) or PI3K, Akt, (McDonald et al., 2006; Wayne et al., 2007) and AMP-activated protein kinase (AMPK) (Kayampilly and Menon, 2009)/Glycogen Synthase Kinase (GSK) $3 \beta$ (Alam et al., 2004, 2009; Fan et al., 2010) has been reported in granulosa cells.

\section{INTEGRATING microRNA REGULATION IN GONADOTROPIN SIGNALING NETWORK}

Based on the importance of microRNAs in the male gonad and in Sertoli cells more specifically, as presented above, it can be anticipated that a complex microRNA network will superimpose intricately with this complex FSH signaling network, to determine the ultimate cell response to the hormone. The first large-scale work exploring this assumption has focused on the molecular bases of spermiation, in a rat model where FSH and testosterone action was suppressed in vivo (Nicholls et al., 2011). At this stage of spermatogenesis, which is particularly sensitive to hormone regulation, elongated spermatids are released away from Sertoli cells, following complex membrane rearrangements. Therefore, this study has focused on signaling mechanisms related to Sertoli cells/germ cells adhesion. By probing a microRNA micro-array, it appeared that 163 microRNAs were responsive to hormone treatment in in vitro Sertoli cells cultured from P20 rats. One of the mRNA candidate targets that came out from this analysis was the pten mRNA (Figure 2) whose $3^{\prime}$ region exhibits putative target sites for miR-23b and miR-217. Individual miR efficiency being weak, it is common that several distinct miR act in concert on a single mRNA, to optimize repression. The hormonal input would lead to degradation or synthesis inhibition of the pten-directed microRNA, resulting in pten mRNA stabilization and protein accumulation in the apical region of the cells, in the vicinity of mature spermatids, possibly to regulate cell adhesion (Nicholls et al., 2011). These data illustrate another property of microRNAs, in the compartmentalization of mRNA to be translated, as previously shown for locally translated transcripts in neurons (Kim et al., 2004).

Interestingly, our group had previously reported that the PTEN protein level was massively enhanced (about 80 -fold above basal in average, at maximum) following in vitro cell stimulation by FSH, leading Sertoli cells to achieve terminal differentiation (Dupont et al., 2010). Given that FSH enhanced PTEN protein level within minutes, we assumed that this regulation occurred post-transcriptionally, in agreement with Stanton's group (Nicholls et al., 2011). However, it appeared that recruitment of the pten mRNA into the polysomes was not increased upon FSH stimulation (Musnier et al., 2012). Therefore, we 


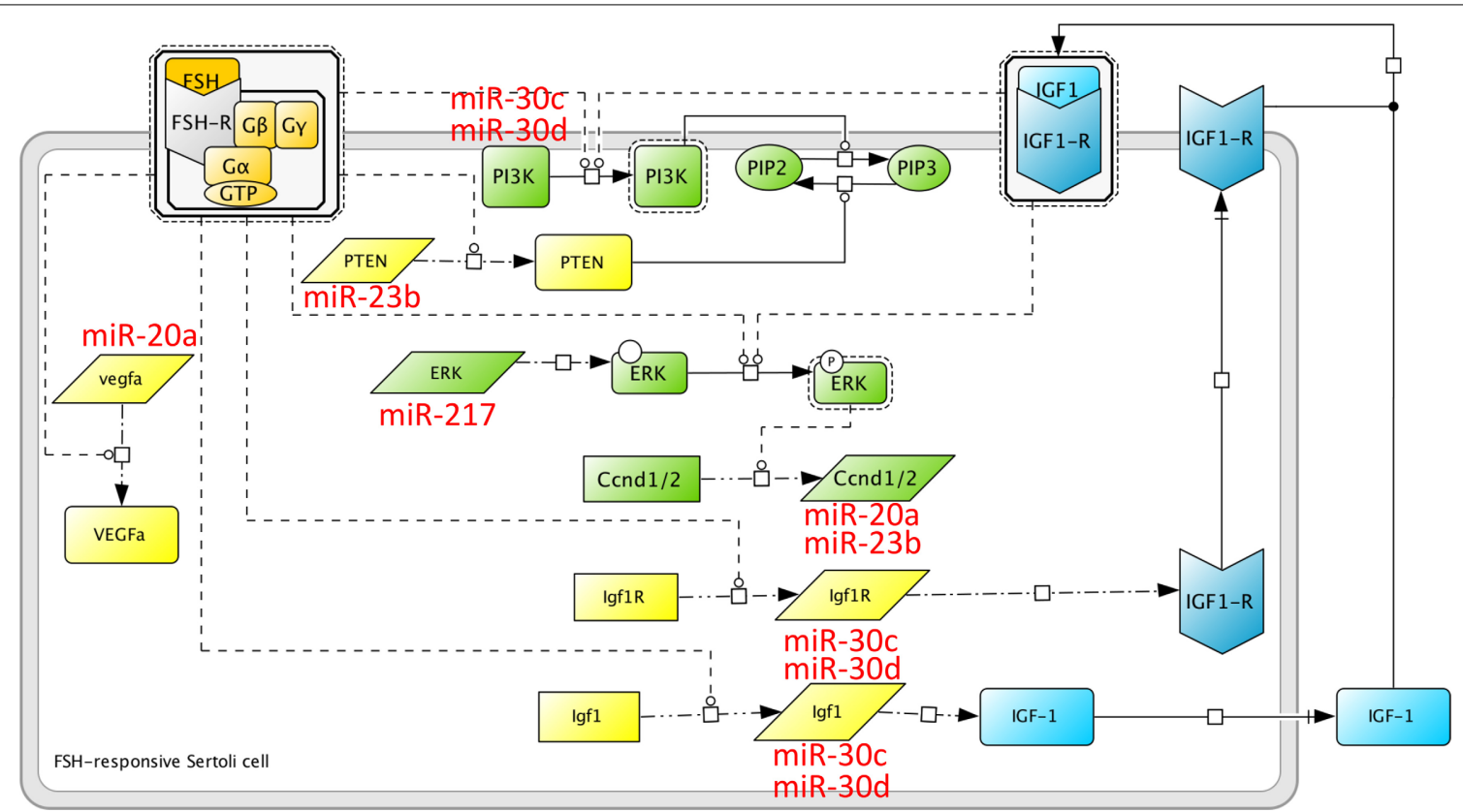

FIGURE 2 | MicroRNA induced by FSH at spermiogenesis. A

microRNA network superimposes on the protein network induced by FSH. Here are shown some microRNAs whose expression is altered upon in vivo FSH suppression, i.e., miR-23b, miR-30c and miR-30d, mir-20a and miR-217, as reported in Nicholls et al. (2011). miR-30c and miR-30d target the IGF-1 system, as well as the PI3K pathway.
According to Khan et al. (2002), PI3K is activated directly by FSH in the prepubertal rat, and indirectly, through the IGF1-R, in the neonate. miR-23b could impair the post-transcriptional regulation of PTEN induced by FSH (Dupont et al., 2010), and could potentially target Cyclin D1. Whether FSH regulates Cyclin D1 at the transcriptional or post-transcriptional level is not known yet. assume that the microRNA targeting the pten mRNA might inhibit the elongation phase of translation, rather than its recruitment into the polysomes. Previous evidence that microRNA could associate to polysomes and block the elongation phase of translation have been provided (Maroney et al., 2006). Nevertheless, the corresponding mechanisms are still unclear (Fabian et al., 2010), and the most recent views now favor an implication of microRNA in translation initiation rather than elongation (Ricci et al., 2013). In contrast to pten, recruitment of the vegfa mRNA to the polysomes is enhanced upon FSH stimulation in Sertoli cells from prepubertal rats (Musnier et al., 2012). The vegf mRNA is a putative target of miR-20a, whose expression is stimulated by FSH at spermiogenesis. Hence, in this case, miR-20a might impact at the level of vegfa mRNA translation initiation.

In addition, Stanton's group bioinformatics analysis also revealed the existence of microRNA targeting components of the ERK pathway that would be repressed in the presence of hormone. This observation, obtained from mature rats, contrasts with our finding that, in pre-pubertal rats, the abundance of ERK MAP kinase is unchanged in FSH-stimulated cells, whereas the phosphorylation level varies (Crépieux et al., 2001).

An important pathway that supports both the mitogenic phase and the nurse cell function of Sertoli cells is the Insulin-like Growth Factor 1 (IGF1)/IGF1 receptor (IGF1-R) system. IGF-I stimulates Sertoli cell proliferation in vitro (Borland et al., 1984) and in vivo ablation of the IGF system (both IGF1-R and Insulin Receptor knock-out) have convincingly entrenched its requirement for FSH-mediated mitogenic action in the pre-pubertal mouse (Pitetti et al., 2013). Based on previous observations, it is admitted that both FSH and IGF-I act on the PI3-K (Froment et al., 2007) and ERK (Crépieux et al., 2001) pathways, both involved in cell proliferation and survival. From Stanton group's analysis, miR-30c and miR-30d appear to be responsive to FSH. These microRNA potentially recognize the IGF1, IGF1-R, and PI3K mRNA (Figure 2), suggesting that the expression of these key effectors of FSH biological action is tightly regulated. In addition, FSH and IGF-I directly impact on cell cycle regulators. For example, both FSH and IGF-I can stimulate the expression of the D1 and D2 cyclins (Crépieux et al., 2001; Pitetti et al., 2013), instrumental in mediating progression through the G1 phase of the cell cycle (Figure 2). In addition to the pten mRNA, miR-23b could also regulate the Cyclin D1 mRNA (Nicholls et al., 2011). We had shown previously that FSH enhanced the level of Cyclin D1 expression in Sertoli cells from neonate rats, but not from prepubertal rats (Crépieux et al., 2001). Therefore, it is conceivable that later on, when spermatogenesis has started, and when Sertoli cell proliferation has ceased, cyclin D1 has to be maintained at a low level within the cell. Furthermore, IGF-I inhibits the transcription of two cell cycle inhibitors, namely the $p 15^{\text {Ink } 4}$ gene (Pitetti et al., 2013) and presumably the $p 21^{\text {Cip }}$ gene (Marx, 1993), via p53 dephosphorylation (Froment et al., 2007) in Sertoli cells.

Later in life, once spermatogenesis is efficient, the FSH-R- and the IGF1-R-transduced signaling share the PI3-K as a common effector to stimulate lactate production in the neonate (Khan et al., 2002), whereas FSH stimulates the PI3-K pathway independently of IGF-I before puberty (Meroni et al., 2004). Lactate production is a key nurturing function of Sertoli cells, which 
metabolize it from glucose that post-meiotic germ cells can then utilize as an energy source. The role of FSH in this process is first to accelerate the transport of glucose within Sertoli cells, presumably through Glucose Transporter 1 (GLUT-1) (Galardo et al., 2008), and second to enhance the activity of lactate dehydrogenase, the enzyme that converts pyruvate to lactate at the end of the metabolic chain.

\section{INSIGHTS ONTO THE REGULATION OF LH ACTION BY microRNAs}

Most functional studies of microRNAs in granulosa cells have focused on the pre-ovulatory surge of $\mathrm{LH}$, a critical period of the ovarian cycle. Several microRNA including miR-21, miR-122, miR-132, miR-212, and miR-136-3p are upregulated following administration of an ovulatory dose of human Choriogonadotropin (hCG) and/or supplementation of granulosa cell culture medium with the hormone (Fiedler et al., 2008; Carletti et al., 2010; Kitahara et al., 2013; Menon et al., 2013). In a functional approach, inhibiting miR-21 or miR-122 affected granulosa cell survival/apoptosis, proliferation or transition to luteinization, supporting a physiological role (Carletti et al., 2010; Menon et al., 2013). Numerous putative targets were predicted using bioinformatics. C-terminal binding protein-1 (CtBP-1), a cofactor of Steroidogenic Factor 1 (SF-1) and co-repressor of nuclear receptors, was actually regulated when blocking miR132 and miR-212 (Fiedler et al., 2008). Finally, miR-136-3p was shown to be involved in destabilizing the LH receptor (LHR) mRNA, contributing to its down-regulation after the $\mathrm{LH}$ surge (Kitahara et al., 2013). Within the ovulatory follicle, a remarkable event is the expansion of the oocyte-surrounding cumulus, which changes from a compact cell mass into a dispersed structure of cells, under the action of several proteins including Pentraxin3. miR-224 was shown to function as a negative regulator of cumulus expansion in vitro and ovulation in vivo by directly targeting Pentraxin3 mRNA, consistent with miR-224 decrease in both granulosa and cumulus cells of hCG-injected immature mice after equine CG treatment (Yao et al., 2013).

In the testis also, Lin28b, an RNA-binding protein that is involved in the biosynthesis of the let-7 microRNA, is expressed in interstitial Leydig cells and its expression might be upregulated by LH/CG (Gaytan et al., 2013). Synthesis of the LH $\beta$ subunit in the pituitary is itself controlled by miR-200b and miR-429, whose knock-out in mouse leads to anovulation (Hasuwa et al., 2013).

\section{FUTURE DIRECTIONS}

Spatial restriction of signaling effectors upon Sertoli cell morphological changes could correlate to differentiation, as suggested by the spatial restriction of FSH-dependent expression of PTEN to the apical region of Sertoli cells (Nicholls et al., 2011). FSH biological function shifts between 9 and 18 days post-partum, prior to the first wave of spermatogenesis in rodents, from first sustaining Sertoli cell proliferation to a role in metabolic and architectural support for germ cells. Not only the gene expression pattern but also the signaling pathways vary as a function of Sertoli cell postdevelopmental stage. Defining the molecular bases of this switch has been the matter of an intensive quest, but many possibilities still remain. An appealing explanation would be a systemic change in the microRNA network, reminiscent of the ongoing hypotheses on the maternal/zygotic transition (Walser and Lipshitz, 2011). This possibility is supported by the fact that, in the course of cell differentiation, microRNAs are considered to consolidate the transcriptional gene expression program by repressing leaky transcripts that were specific of the anterior, less differentiated stage (Stark et al., 2005). By these means they would support tissue identity (Farh et al., 2005; Sood et al., 2006). A genomewide analysis of FSH-regulated microRNAs at different Sertoli cell developmental stages could probably address this option. With more than $60 \%$ of protein-coding genes being computationally predicted as microRNA targets (Friedman et al., 2009), bioinformatics analyses at the systems level should soon identify potential microRNA target sites in gonadotropin-induced transcriptome/translatome, with an unprecedented throughput. This will allow taking into account the microRNA regulation level in systems biology of gonadotropin signaling networks.

Beyond their physiological role, gonadotropin biological action can be hijacked in pathological disturbances such as cancer or infertility. For example, FSH can enhance ovarian cancer cells proliferation through the PI3K/Akt signal pathway (Choi et al., 2002). Induction of Vascular Endothelial Growth Factor, Cyclooxygenase 2 and survivin expression by FSH in such cells was recently reported to involve miR-27a (Lai et al., 2013). On the other hand, the screening of a high density Ovarian Cancer Disease Specific Array with human ovarian carcinoma cell mRNA suggests that LH may reduce cancer cell proliferation via some regulatory microRNAs (Cui et al., 2011a,b).

It has been proposed that some cellular mRNA act as bona fide microRNA target in one cell type or in defined physiological conditions, but as a microRNA-sequestering molecule in other cell type or conditions (Seitz, 2009). For example, endogenous transcripts named "competitive endogenous RNAs" (ceRNAs) appear to act as natural microRNA decoys (Tay et al., 2011). One of the major conundrums that preclude reaching the real dynamics of interactions between all of these actors is the quantitative determination of the relative ratio of microRNAs vs. ceRNA within the cell. Notably, the pten mRNA bears such a "non-coding" function. So far, this dimension is still out of reach regarding the regulation of gonadotropin signaling network, but no doubt that a comprehensive view of these networks will have to integrate these multidimensional regulations.

\section{ACKNOWLEDGMENTS}

Kelly León was funded by a fellowship from the Region Centre, and Nathalie Gallay was funded by a fellowship from the Agence Nationale de la Recherche (ANR) Program GPCRnet. This work was supported by the Institut National de la Recherche Agronomique (INRA) and by the Centre National de la Recherche Scientifique (CNRS).

\section{REFERENCES}

Alam, H., Maizels, E. T., Park, Y., Ghaey, S., Feiger, Z. J., Chandel, N. S., et al. (2004). Follicle-stimulating hormone activation of hypoxia-inducible factor1 by the phosphatidylinositol 3-kinase/AKT/Ras homolog enriched in brain (Rheb)/mammalian target of rapamycin (mTOR) pathway is necessary for induction of select protein markers of follicular differentiation. J. Biol. Chem 279, 19431-19440. doi: 10.1074/jbc.M401235200

Alam, H., Weck, J., Maizels, E., Park, Y., Lee, E. J., Ashcroft, M., et al. (2009). Role of the phosphatidylinositol-3-kinase and extracellular regulated kinase 
pathways in the induction of hypoxia-inducible factor (HIF)-1 activity and the HIF-1 target vascular endothelial growth factor in ovarian granulosa cells in response to follicle-stimulating hormone. Endocrinology 150, 915-928. doi: 10.1210/en.2008-0850

Andric, N., and Ascoli, M. (2006). A delayed gonadotropin-dependent and growth factor-mediated activation of the extracellular signal-regulated kinase $1 / 2$ cascade negatively regulates aromatase expression in granulosa cells. Mol. Endocrinol. 20, 3308-3320. doi: 10.1210/me.2006-0241

Arey, B. J., Stevis, P. E., Deecher, D. C., Shen, E. S., Frail, D. E., NegroVilar, A., et al. (1997). Induction of promiscuous $G$ protein coupling of the follicle-stimulating hormone (FSH) receptor: a novel mechanism for transducing pleiotropic actions of FSH isoforms. Mol. Endocrinol. 11, 517-526. doi: 10.1210/me.11.5.517

Barad, O., Meiri, E., Avniel, A., Aharonov, R., Barzilai, A., Bentwich, I., et al. (2004). MicroRNA expression detected by oligonucleotide microarrays: system establishment and expression profiling in human tissues. Genome Res. 14, 2486-2494. doi: 10.1101/gr.2845604

Bernstein, E., Kim, S. Y., Carmell, M. A., Murchison, E. P., Alcorn, H., Li, M. Z., et al. (2003). Dicer is essential for mouse development. Nat. Genet. 35, 215-217. doi: $10.1038 / \mathrm{ng} 1253$

Borland, K., Mita, M., Oppenheimer, C. L., Blinderman, L. A., Massague, J., Hall, P. F., et al. (1984). The actions of insulin-like growth factors I and II on cultured Sertoli cells. Endocrinology 114, 240-246. doi: 10.1210/endo-114-1-240

Carletti, M. Z., Fiedler, S. D., and Christenson, L. K. (2010). MicroRNA 21 blocks apoptosis in mouse periovulatory granulosa cells. Biol. Reprod. 83, 286-295. doi: 10.1095/biolreprod.109.081448

Choi, J. H., Chen, C. L., Poon, S. L., Wang, H. S., and Leung, P. C. (2009). Gonadotropin-stimulated epidermal growth factor receptor expression in human ovarian surface epithelial cells: involvement of cyclic AMP-dependent exchange protein activated by cAMP pathway. Endocr. Relat. Cancer 16, 179-188. doi: 10.1677/ERC-07-0238

Choi, K. C., Kang, S. K., Tai, C. J., Auersperg, N., and Leung, P. C. (2002). Follicle-stimulating hormone activates mitogen-activated protein kinase in preneoplastic and neoplastic ovarian surface epithelial cells. J. Clin. Endocrinol. Metab. 87, 2245-2253. doi: 10.1210/jc.87.5.2245

Cottom, J., Salvador, L. M., Maizels, E. T., Reierstad, S., Park, Y., Carr, D. W., et al. (2003). Follicle-stimulating hormone activates extracellular signalregulated kinase but not extracellular signal-regulated kinase kinase through a 100-kDa phosphotyrosine phosphatase. J. Biol. Chem. 278, 7167-7179. doi: 10.1074/jbc.M203901200

Crépieux, P., Marion, S., Martinat, N., Fafeur, V., Vern, Y. L., Kerboeuf, D., et al. (2001). The ERK-dependent signalling is stage-specifically modulated by FSH, during primary Sertoli cell maturation. Oncogene 20, 4696-4709. doi: 10.1038/sj.onc.1204632

Cui, J., Eldredge, J. B., Xu, Y., and Puett, D. (2011a). MicroRNA expression and regulation in human ovarian carcinoma cells by luteinizing hormone. PLoS ONE 6:e21730. doi: 10.1371/journal.pone.0021730

Cui, J., Miner, B. M., Eldredge, J. B., Warrenfeltz, S. W., Dam, P., Xu, Y., et al. (2011b). Regulation of gene expression in ovarian cancer cells by luteinizing hormone receptor expression and activation. BMC Cancer 11:280. doi: 10.1186/1471-2407-11-280

Cui, Q., Yu, Z., Purisima, E. O., and Wang, E. (2006). Principles of microRNA regulation of a human cellular signaling network. Mol. Syst. Biol. 2:46. doi: $10.1038 / \mathrm{msb} 4100089$

Dattatreyamurty, B., Figgs, L. W., and Reichert, L. E. Jr. (1987). Physical and functional association of follitropin receptors with cholera toxin-sensitive guanine nucleotide-binding protein. J. Biol. Chem. 262, 11737-11745.

de Cuevas, M., and Matunis, E. L. (2011). The stem cell niche: lessons from the Drosophila testis. Development 138, 2861-2869. doi: 10.1242/dev.056242

Dupont, J., Musnier, A., Decourtye, J., Boulo, T., Lécureuil, C., Guillou, H., et al. (2010). FSH-stimulated PTEN activity accounts for the lack of FSH mitogenic effect in prepubertal rat Sertoli cells. Mol. Cell. Endocrinol. 315, 271-276. doi: 10.1016/j.mce.2009.09.016

Escamilla-Hernandez, R., Little-Ihrig, L., Orwig, K. E., Yue, J., Chandran, U., and Zeleznik, A. J. (2008). Constitutively active protein kinase A qualitatively mimics the effects of follicle-stimulating hormone on granulosa cell differentiation. Mol. Endocrinol. 22, 1842-1852. doi: 10.1210/me.2008-0103

Fabian, M. R., Sonenberg, N., and Filipowicz, W. (2010). Regulation of mRNA translation and stability by microRNAs. Annu. Rev. Biochem. 79, 351-379. doi: 10.1146/annurev-biochem-060308-103103
Fan, H. Y., O’Connor, A., Shitanaka, M., Shimada, M., Liu, Z., and Richards, J. S. (2010). Beta-catenin (CTNNB1) promotes preovulatory follicular development but represses LH-mediated ovulation and luteinization. Mol. Endocrinol. 24, 1529-1542. doi: 10.1210/me.2010-0141

Farh, K. K., Grimson, A., Jan, C., Lewis, B. P., Johnston, W. K., Lim, L. P., et al. (2005). The widespread impact of mammalian MicroRNAs on mRNA repression and evolution. Science 310, 1817-1821. doi: 10.1126/science.1121158

Fiedler, S. D., Carletti, M. Z., Hong, X., and Christenson, L. K. (2008). Hormonal regulation of MicroRNA expression in periovulatory mouse mural granulosa cells. Biol. Reprod. 79, 1030-1037. doi: 10.1095/biolreprod.108.069690

Flemr, M., Malik, R., Franke, V., Nejepinska, J., Sedlacek, R., Vlahovicek, K., et al. (2013). A retrotransposon-driven dicer isoform directs endogenous small interfering RNA production in mouse oocytes. Cell 155, 807-816. doi: 10.1016/j.cell.2013.10.001

Forstemann, K., Tomari, Y., Du, T., Vagin, V. V., Denli, A. M., Bratu, D. P., et al. (2005). Normal microRNA maturation and germ-line stem cell maintenance requires Loquacious, a double-stranded RNA-binding domain protein. PLoS Biol. 3:e236. doi: 10.1371/journal.pbio.0030236

Friedman, R. C., Farh, K. K., Burge, C. B., and Bartel, D. P. (2009). Most mammalian mRNAs are conserved targets of microRNAs. Genome Res. 19, 92-105. doi: 10.1101/gr.082701.108

Froment, P., Vigier, M., Negre, D., Fontaine, I., Beghelli, J., Cosset, F. L., et al. (2007). Inactivation of the IGF-I receptor gene in primary Sertoli cells highlights the autocrine effects of IGF-I. J. Endocrinol. 194, 557-568. doi: 10.1677/JOE-070258

Fuller, M. T., and Spradling, A. C. (2007). Male and female Drosophila germline stem cells: two versions of immortality. Science 316, 402-404. doi: 10.1126/science. 1140861

Galardo, M. N., Riera, M. F., Pellizzari, E. H., Chemes, H. E., Venara, M. C., Cigorraga, S. B., et al. (2008). Regulation of expression of Sertoli cell glucose transporters 1 and 3 by FSH, ILl beta, and bFGF at two different time-points in pubertal development. Cell Tissue Res. 334, 295-304. doi: 10.1007/s00441-0080656-y

Gaytan, F., Sangiao-Alvarellos, S., Manfredi-Lozano, M., Garcia-Galiano, D., RuizPino, F., Romero-Ruiz, A., et al. (2013). Distinct expression patterns predict differential roles of the miRNA-binding proteins, Lin28 and Lin28b, in the mouse testis: studies during postnatal development and in a model of hypogonadotropic hypogonadism. Endocrinology 154, 1321-1336. doi: 10.1210/en.2012-1745

Gloaguen, P., Crépieux, P., Heitzler, D., Poupon, A., and Reiter, E. (2011). Mapping the follicle-stimulating hormone-induced signaling networks. Front. Endocrinol. 2:45. doi: 10.3389/fendo.2011.00045

Gonzalez, G., and Behringer, R. R. (2009). Dicer is required for female reproductive tract development and fertility in the mouse. Mol. Reprod. Dev. 76, 678-688. doi: $10.1002 / \mathrm{mrd} .21010$

Gonzalez-Gonzalez, E., Lopez-Casas, P. P., and del Mazo, J. (2008a). The expression patterns of genes involved in the RNAi pathways are tissue-dependent and differ in the germ and somatic cells of mouse testis. Biochim. Biophys. Acta 1779, 306-311. doi: 10.1016/j.bbagrm.2008.01.007

Gonzalez-Gonzalez, E., Lopez-Casas, P. P., and Del Mazo, J. (2008b). Gene silencing by RNAi in mouse Sertoli cells. Reprod. Biol. Endocrinol. 6:29. doi 10.1186/1477-7827-6-29

Gonzalez-Robayna, I. J., Falender, A. E., Ochsner, S., Firestone, G. L., and Richards, J. S. (2000). Follicle-Stimulating hormone (FSH) stimulates phosphorylation and activation of protein kinase $\mathrm{B}$ (PKB/Akt) and serum and glucocorticoidlnduced kinase (Sgk): evidence for A kinase-independent signaling by FSH in granulosa cells. Mol. Endocrinol. 14, 1283-1300. doi: 10.1210/me.14. 8.1283

Guo, H., Ingolia, N. T., Weissman, J. S., and Bartel, D. P. (2010). Mammalian microRNAs predominantly act to decrease target mRNA levels. Nature 466, 835-840. doi: 10.1038/nature09267

Hasuwa, H., Ueda, J., Ikawa, M., and Okabe, M. (2013). miR-200b and miR-429 function in mouse ovulation and are essential for female fertility. Science 341 , 71-73. doi: 10.1126/science. 1237999

Hayashi, K., Chuva de Sousa Lopes, S. M., Kaneda, M., Tang, F., Hajkova, P., Lao, K., et al. (2008). MicroRNA biogenesis is required for mouse primordial germ cell development and spermatogenesis. PLOS ONE 3:e1738. doi: 10.1371/journal.pone.0001738

Hong, X., Luense, L. J., McGinnis, L. K., Nothnick, W. B., and Christenson, L. K. (2008). Dicerl is essential for female fertility and normal development 
of the female reproductive system. Endocrinology 149, 6207-6212. doi: 10.1210/en.2008-0294

Huang, C. C., and Yao, H. H. (2010). Inactivation of Dicer1 in Steroidogenic factor 1-positive cells reveals tissue-specific requirement for Dicer1 in adrenal, testis, and ovary. BMC Dev. Biol. 10:66. doi: 10.1186/1471-213X-10-66

Jin, Z., and Xie, T. (2007). Dcr-1 maintains Drosophila ovarian stem cells. Curr. Biol. 17, 539-544. doi: 10.1016/j.cub.2007.01.050

Johanson, T. M., Lew, A. M., and Chong, M. M. (2013). MicroRNA-independent roles of the RNase III enzymes Drosha and Dicer. Open Biol. 3:130144. doi: 10.1098/rsob.130144

Kaneda, M., Tang, F., O’Carroll, D., Lao, K., and Surani, M. A. (2009). Essential role for Argonaute2 protein in mouse oogenesis. Epigenetics Chromatin 2:9. doi: 10.1186/1756-8935-2-9

Kara, E., Crépieux, P., Gauthier, C., Martinat, N., Piketty, V., Guillou, F., et al. (2006). A phosphorylation cluster of five serine and threonine residues in the C-terminus of the follicle-stimulating hormone receptor is important for desensitization but not for beta-arrestin-mediated ERK activation. Mol. Endocrinol. 20, 3014-3026. doi: 10.1210/me.2006-0098

Kayampilly, P. P., and Menon, K. M. (2009). Follicle-stimulating hormone inhibits adenosine 5'-monophosphate-activated protein kinase activation and promotes cell proliferation of primary granulosa cells in culture through an Akt-dependent pathway. Endocrinology 150, 929-935. doi: 10.1210/en.20081032

Khan, S. A., Ndjountche, L., Pratchard, L., Spicer, L. J., and Davis, J. S. (2002). Follicle-stimulating hormone amplifies insulin-like growth factor I-mediated activation of AKT/protein kinase B signaling in immature rat Sertoli cells. Endocrinology 143, 2259-2267. doi: 10.1210/en.143.6.2259

Kim, J., Krichevsky, A., Grad, Y., Hayes, G. D., Kosik, K. S., Church, G. M., et al. (2004). Identification of many microRNAs that copurify with polyribosomes in mammalian neurons. Proc. Natl. Acad. Sci. U.S.A. 101, 360-365. doi: $10.1073 /$ pnas. 2333854100

Kirilly, D., and Xie, T. (2007). The Drosophila ovary: an active stem cell community. Cell Res. 17, 15-25. doi: 10.1038/sj.cr.7310123

Kitahara, Y., Nakamura, K., Kogure, K., and Minegishi, T. (2013). Role of microRNA-136-3p on the expression of luteinizing hormone-human chorionic gonadotropin receptor mRNA in rat ovaries. Biol. Reprod. 89, 1-10. doi: 10.1095/biolreprod.113.109207

Korhonen, H. M., Meikar, O., Yadav, R. P., Papaioannou, M. D., Romero, Y., Da Ros, M., et al. (2011). Dicer is required for haploid male germ cell differentiation in mice. PLoS ONE 6:e24821. doi: 10.1371/journal.pone.0024821

Kotaja, N., Bhattacharyya, S. N., Jaskiewicz, L., Kimmins, S., Parvinen, M., Filipowicz, W., et al. (2006). The chromatoid body of male germ cells: similarity with processing bodies and presence of Dicer and microRNA pathway components. Proc. Natl. Acad. Sci. U.S.A. 103, 2647-2652. doi: 10.1073/pnas.0 509333103

Lai, Y., Zhang, X., Zhang, Z., Shu, Y., Luo, X., Yang, Y., et al. (2013). The microRNA27a: ZBTB10-specificity protein pathway is involved in follicle stimulating hormone-induced VEGF, Cox2 and survivin expression in ovarian epithelial cancer cells. Int. J. Oncol. 42, 776-784. doi: 10.3892/ijo.2012.1743

Lécureuil, C., Tesseraud, S., Kara, E., Martinat, N., Sow, A., Fontaine, I., et al. (2005). Follicle-stimulating hormone activates p70 ribosomal protein S6 kinase by protein kinase A-mediated dephosphorylation of Thr 421/Ser 424 in primary Sertoli cells. Mol. Endocrinol. 19, 1812-1820. doi: 10.1210/me.2004-0289

Lee, R. C., Feinbaum, R. L., and Ambros, V. (1993). The C. elegans heterochronic gene lin-4 encodes small RNAs with antisense complementarity to lin-14. Cell 75, 843-854. doi: 10.1016/0092-8674(93)90529-Y

Lee, Y., Ahn, C., Han, J., Choi, H., Kim, J., Yim, J., et al. (2003). The nuclear RNase III Drosha initiates microRNA processing. Nature 425, 415-419. doi: 10.1038/nature01957

Lee, Y. S., Nakahara, K., Pham, J. W., Kim, K., He, Z., Sontheimer, E. J., et al. (2004). Distinct roles for Drosophila Dicer-1 and Dicer-2 in the siRNA/miRNA silencing pathways. Cell 117, 69-81. doi: 10.1016/S0092-8674(04)00261-2

Lei, L., Jin, S., Gonzalez, G., Behringer, R. R., and Woodruff, T. K. (2010). The regulatory role of Dicer in folliculogenesis in mice. Mol. Cell. Endocrinol. 315, 63-73. doi: 10.1016/j.mce.2009.09.021

Lin, X., Rice, K. L., Buzzai, M., Hexner, E., Costa, F. F., Kilpivaara, O., et al. (2013). miR-433 is aberrantly expressed in myeloproliferative neoplasms and suppresses hematopoietic cell growth and differentiation. Leukemia 27, 344-352. doi: 10.1038/leu.2012.224
Liu, C. G., Calin, G. A., Meloon, B., Gamliel, N., Sevignani, C., Ferracin, M., et al. (2004). An oligonucleotide microchip for genome-wide microRNA profiling in human and mouse tissues. Proc. Natl. Acad. Sci. U.S.A. 101, 9740-9744. doi: 10.1073/pnas.0403293101

Liu, H. C., Tang, Y., He, Z., and Rosenwaks, Z. (2010). Dicer is a key player in oocyte maturation. J. Assist. Reprod. Genet. 27, 571-580. doi: 10.1007/s10815010-9456-X

Loss, E. S., Jacobus, A. P., and Wassermann, G. F. (2007). Diverse FSH and testosterone signaling pathways in the Sertoli cell. Horm. Metab. Res. 39, 806-812. doi: 10.1055/s-2007-991167

Ma, J., Flemr, M., Stein, P., Berninger, P., Malik, R., Zavolan, M., et al. (2010). MicroRNA activity is suppressed in mouse oocytes. Curr. Biol. 20, 265-270. doi: 10.1016/j.cub.2009.12.042

Maatouk, D. M., Loveland, K. L., McManus, M. T., Moore, K., and Harfe, B. D. (2008). Dicer 1 is required for differentiation of the mouse male germline. Biol. Reprod. 79, 696-703. doi: 10.1095/biolreprod.108.067827

Maizels, E. T., Cottom, J., Jones, J. C., and Hunzicker-Dunn, M. (1998). Follicle stimulating hormone ( $\mathrm{FSH}$ ) activates the $\mathrm{p} 38$ mitogen-activated protein kinase pathway, inducing small heat shock protein phosphorylation and cell rounding in immature rat ovarian granulosa cells. Endocrinology 139, 3353-3356. doi: 10.1210/en.139.7.3353

Marcon, E., Babak, T., Chua, G., Hughes, T., and Moens, P. B. (2008). miRNA and piRNA localization in the male mammalian meiotic nucleus. Chromosome Res. 16, 243-260. doi: 10.1007/s10577-007-1190-6

Maroney, P. A., Yu, Y., Fisher, J., and Nilsen, T. W. (2006). Evidence that microRNAs are associated with translating messenger RNAs in human cells. Nat. Struct. Mol. Biol. 13, 1102-1107. doi: 10.1038/nsmb1174

Marx, J. (1993). How p53 suppresses cell growth. Science 262, 1644-1645. doi: $10.1126 /$ science. 8259506

Mattiske, D. M., Han, L., and Mann, J. R. (2009). Meiotic maturation failure induced by DICER1 deficiency is derived from primary oocyte ooplasm. Reproduction 137, 625-632. doi: 10.1530/REP-08-0475

McDonald, C. A., Millena, A. C., Reddy, S., Finlay, S., Vizcarra, J., Khan, S. A., et al. (2006). Follicle-stimulating hormone-induced aromatase in immature rat Sertoli cells requires an active phosphatidylinositol 3-kinase pathway and is inhibited via the mitogen-activated protein kinase signaling pathway. Mol. Endocrinol. 20, 608-618. doi: 10.1210/me.2005-0245

McLean, D. J., Friel, P. J., Pouchnik, D., and Griswold, M. D. (2002). Oligonucleotide microarray analysis of gene expression in follicle-stimulating hormone-treated rat Sertoli cells. Mol. Endocrinol. 16, 2780-2792. doi: 10.1210/ me.2002-0059

Meachem, S. J., Ruwanpura, S. M., Ziolkowski, J., Ague, J. M., Skinner, M. K., and Loveland, K. L. (2005). Developmentally distinct in vivo effects of FSH on proliferation and apoptosis during testis maturation. J. Endocrinol. 186, 429-446. doi: $10.1677 /$ joe.1.06121

Means, A. R., MacDougall, E., Soderling, T. R., and Corbin, J. D. (1974). Testicular adenosine 3':5'-monophosphate-dependent protein kinase. Regulation by follicle-stimulating hormone. J. Biol. Chem. 249, 1231-1238.

Menon, B., Sinden, J., Franzo-Romain, M., Botta, R. B., and Menon, K. M. (2013). Regulation of LH receptor mRNA binding protein by miR-122 in rat ovaries. Endocrinology 154, 4826-4834. doi: 10.1210/en.2013-1619

Meroni, S. B., Riera, M. F., Pellizzari, E. H., Galardo, M. N., and Cigorraga, S. B. (2004). FSH activates phosphatidylinositol 3-kinase/protein kinase B signaling pathway in 20-day-old Sertoli cells independently of IGF-I. J. Endocrinol. 180, 257-265. doi: 10.1677/joe.0.1800257

Morita, S., Horii, T., Kimura, M., Goto, Y., Ochiya, T., and Hatada, I. (2007). One Argonaute family member, Eif2c2 (Ago2), is essential for development and appears not to be involved in DNA methylation. Genomics 89, 687-696. doi: 10.1016/j.ygeno.2007.01.004

Murchison, E. P., Partridge, J. F., Tam, O. H., Cheloufi, S., and Hannon, G. J. (2005). Characterization of Dicer-deficient murine embryonic stem cells. Proc. Natl. Acad. Sci. U.S.A. 102, 12135-12140. doi: 10.1073/pnas. 0505479102

Musnier, A., Blanchot, B., Reiter, E., and Crepieux, P. (2010). GPCR signalling to the translation machinery. Cell. Signal. 22, 707-716. doi: 10.1016/j.cellsig.2009. 10.012

Musnier, A., León, K., Morales, J., Reiter, E., Boulo, T., Costache, V., et al. (2012). mRNA-selective translation induced by FSH in primary Sertoli cells. Mol. Endocrinol. 26, 669-680. doi: 10.1210/me.2011-1267 
Nagaraja, A. K., Andreu-Vieyra, C., Franco, H. L., Ma, L., Chen, R., Han, D. Y., et al. (2008). Deletion of dicer in somatic cells of the female reproductive tract causes sterility. Mol. Endocrinol. 22, 2336-2352. doi: 10.1210/me.2008-0142

Nechamen, C. A., Thomas, R. M., Cohen, B. D., Acevedo, G., Poulikakos, P. I., Testa, J. R., et al. (2004). Human follicle-stimulating hormone (FSH) receptor interacts with the adaptor protein APPL1 in HEK 293 cells: potential involvement of the PI3K pathway in FSH signaling. Biol. Reprod. 71, 629-636. doi: 10.1095/biolreprod.103.025833

Nechamen, C. A., Thomas, R. M., and Dias, J. A. (2007). APPL1, APPL2, Akt2 and FOXO1a interact with FSHR in a potential signaling complex. Mol. Cell. Endocrinol. 260-262, 93-99. doi: 10.1016/j.mce.2006.08.014

Nicholls, P. K., Harrison, C. A., Walton, K. L., McLachlan, R. I., O’Donnell, L., and Stanton, P. G. (2011). Hormonal regulation of sertoli cell micro-RNAs at spermiation. Endocrinology 152, 1670-1683. doi: 10.1210/en.2010-1341

Pancratov, R., Peng, F., Smibert, P., Yang, J. S., Olson, E. R., Guha-Gilford, C., et al. (2013). The miR-310/13 cluster antagonizes beta-catenin function in the regulation of germ and somatic cell differentiation in the Drosophila testis. Development 140, 2904-2916. doi: 10.1242/dev.092817

Papaioannou, M. D., Lagarrigue, M., Vejnar, C. E., Rolland, A. D., Kuhne, F., Aubry, F., et al. (2011). Loss of Dicer in Sertoli cells has a major impact on the testicular proteome of mice. Mol. Cell. Proteomics 10:M900587MCP900200. doi: 10.1074/mcp.M900587-MCP200

Papaioannou, M. D., Pitetti, J. L., Ro, S., Park, C., Aubry, F., Schaad, O., et al. (2009). Sertoli cell Dicer is essential for spermatogenesis in mice. Dev. Biol. 326, 250-259. doi: 10.1016/j.ydbio.2008.11.011

Pek, J. W., Lim, A. K., and Kai, T. (2009). Drosophila maelstrom ensures proper germline stem cell lineage differentiation by repressing microRNA-7. Dev. Cell 17, 417-424. doi: 10.1016/j.devcel.2009.07.017

Perlman, S., Bouquin, T., van den Hazel, B., Jensen, T. H., Schambye, H. T., Knudsen, S., et al. (2006). Transcriptome analysis of FSH and FSH variant stimulation in granulosa cells from IVM patients reveals novel regulated genes. Mol. Hum. Reprod. 12, 135-144. doi: 10.1093/molehr/gah247

Pitetti, J. L., Calvel, P., Zimmermann, C., Conne, B., Papaioannou, M. D., Aubry, F., et al. (2013). An essential role for insulin and IGF1 receptors in regulating sertoli cell proliferation, testis size, and FSH action in mice. Mol. Endocrinol. 27, 814-827. doi: 10.1210/me.2012-1258

Reiter, E., and Lefkowitz, R. J. (2006). GRKs and beta-arrestins: roles in receptor silencing, trafficking and signaling. Trends Endocrinol. Metab. 17, 159-165. doi: 10.1016/j.tem.2006.03.008

Ricci, E. P., Limousin, T., Soto-Rifo, R., Rubilar, P. S., Decimo, D., and Ohlmann, T. (2013). miRNA repression of translation in vitro takes place during $43 \mathrm{~S}$ ribosomal scanning. Nucleic Acids Res. 41, 586-598. doi: 10.1093/nar/gks1076

Richards, J. S., and Pangas, S. A. (2010). The ovary: basic biology and clinical implications. J. Clin. Invest. 120, 963-972. doi: 10.1172/JCI41350

Ro, S., Park, C., Sanders, K. M., McCarrey, J. R., and Yan, W. (2007a). Cloning and expression profiling of testis-expressed microRNAs. Dev. Biol. 311, 592-602. doi: 10.1016/j.ydbio.2007.09.009

Ro, S., Song, R., Park, C., Zheng, H., Sanders, K. M., and Yan, W. (2007b). Cloning and expression profiling of small RNAs expressed in the mouse ovary. RNA 13, 2366-2380. doi: 10.1261/rna.754207

Romero, Y., Meikar, O., Papaioannou, M. D., Conne, B., Grey, C., Weier, M., et al. (2011). Dicer1 depletion in male germ cells leads to infertility due to cumulative meiotic and spermiogenic defects. PLOS ONE 6:e25241. doi: 10.1371/journal.pone.0025241

Sadate-Ngatchou, P. I., Pouchnik, D. J., and Griswold, M. D. (2004). Folliclestimulating hormone induced changes in gene expression of murine testis. Mol. Endocrinol. 18, 2805-2816. doi: 10.1210/me.2003-0203

Sasson, R., Dantes, A., Tajima, K., and Amsterdam, A. (2003). Novel genes modulated by FSH in normal and immortalized FSH-responsive cells: new insights into the mechanism of FSH action. FASEB J. 17, 1256-1266. doi: 10.1096/fj.020740com

Seitz, H. (2009). Redefining microRNA targets. Curr. Biol. 19, 870-873. doi: 10.1016/j.cub.2009.03.059

Sellami, A., Agricola, H. J., and Veenstra, J. A. (2011). Neuroendocrine cells in Drosophila melanogaster producing GPA2/GPB5, a hormone with homology to LH, FSH and TSH. Gen. Comp. Endocrinol. 170, 582-588. doi: 10.1016/j.ygcen. 2010.11.015

Shoji, M., Chuma, S., Yoshida, K., Morita, T., and Nakatsuji, N. (2005). RNA interference during spermatogenesis in mice. Dev. Biol. 282, 524-534. doi: 10.1016/ j.ydbio.2005.03.030
Sood, P., Krek, A., Zavolan, M., Macino, G., and Rajewsky, N. (2006). Cell-typespecific signatures of microRNAs on target mRNA expression. Proc. Natl. Acad. Sci. U.S.A. 103, 2746-2751. doi: 10.1073/pnas.0511045103

Stark, A., Brennecke, J., Bushati, N., Russell, R. B., and Cohen, S. M. (2005). Animal MicroRNAs confer robustness to gene expression and have a significant impact on 3'UTR evolution. Cell 123, 1133-1146. doi: 10.1016/j.cell.2005.11.023

Suh, N., Baehner, L., Moltzahn, F., Melton, C., Shenoy, A., Chen, J., et al. (2010). MicroRNA function is globally suppressed in mouse oocytes and early embryos. Curr. Biol. 20, 271-277. doi: 10.1016/j.cub.2009.12.044

Tam, O. H., Aravin, A. A., Stein, P., Girard, A., Murchison, E. P., Cheloufi, S., et al. (2008). Pseudogene-derived small interfering RNAs regulate gene expression in mouse oocytes. Nature 453, 534-538. doi: 10.1038/nature06904

Tanaka, H., and Baba, T. (2005). Gene expression in spermiogenesis. Cell. Mol. Life Sci. 62, 344-354. doi: 10.1007/s00018-004-4394-y

Tang, K. F., Wang, Y., Wang, P., Chen, M., Chen, Y., Hu, H. D., et al. (2007). Upregulation of PHLDA2 in Dicer knockdown HEK293 cells. Biochim. Biophys. Acta 1770, 820-825. doi: 10.1016/j.bbagen.2007.01.004

Tay, Y., Kats, L., Salmena, L., Weiss, D., Tan, S. M., Ala, U., et al. (2011). Coding-independent regulation of the tumor suppressor PTEN by competing endogenous mRNAs. Cell 147, 344-357. doi: 10.1016/j.cell.2011.09.029

Thomas, R. M., Nechamen, C. A., Mazurkiewicz, J. E., Ulloa-Aguirre, A., and Dias, J. A. (2011). The adapter protein APPL1 links FSH receptor to inositol 1,4,5-trisphosphate production and is implicated in intracellular $\mathrm{Ca}(2+)$ mobilization. Endocrinology 152, 1691-1701. doi: 10.1210/en.2010-1353

Tranchant, T., Durand, G., Gauthier, C., Crépieux, P., Ulloa-Aguirre, A., Royère, D., et al. (2011). Preferential beta-arrestin signalling at low receptor density revealed by functional characterization of the human FSH receptor A189 V mutation. Mol. Cell. Endocrinol. 331, 109-118. doi: 10.1016/j.mce.2010.08.016

Tsang, J., Zhu, J., and van Oudenaarden, A. (2007). MicroRNA-mediated feedback and feedforward loops are recurrent network motifs in mammals. Mol. Cell 26, 753-767. doi: 10.1016/j.molcel.2007.05.018

Ulloa-Aguirre, A., Crepieux, P., Poupon, A., Maurel, M. C., and Reiter, E. (2011). Novel pathways in gonadotropin receptor signaling and biased agonism. Rev. Endocr. Metab. Disord. 12, 259-274. doi: 10.1007/s11154-011-9176-2

Vasudevan, S., Tong, Y., and Steitz, J. A. (2007). Switching from repression to activation: microRNAs can up-regulate translation. Science 318, 1931-1934. doi: $10.1126 /$ science. 1149460

Voog, J., and Jones, D. L. (2010). Stem cells and the niche: a dynamic duo. Cell Stem Cell 6, 103-115. doi: 10.1016/j.stem.2010.01.011

Walser, C. B., and Lipshitz, H. D. (2011). Transcript clearance during the maternal-to-zygotic transition. Curr. Opin. Genet. Dev. 21, 431-443. doi: 10.1016/j.gde.2011.03.003

Wang, Y., Medvid, R., Melton, C., Jaenisch, R., and Blelloch, R. (2007). DGCR8 is essential for microRNA biogenesis and silencing of embryonic stem cell selfrenewal. Nat. Genet. 39, 380-385. doi: 10.1038/ng1969

Watanabe, T., Imai, H., and Minami, N. (2008a). Identification and expression analysis of small RNAs during development. Methods Mol. Biol. 442, 173-185. doi: 10.1007/978-1-59745-191-8_13

Watanabe, T., Totoki, Y., Toyoda, A., Kaneda, M., Kuramochi-Miyagawa, S., Obata, Y., et al. (2008b). Endogenous siRNAs from naturally formed dsRNAs regulate transcripts in mouse oocytes. Nature 453, 539-543. doi: 10.1038/nature 06908

Wayne, C. M., Fan, H. Y., Cheng, X., and Richards, J. S. (2007). Follicle-stimulating hormone induces multiple signaling cascades: evidence that activation of Rous sarcoma oncogene, RAS, and the epidermal growth factor receptor are critical for granulosa cell differentiation. Mol. Endocrinol. 21, 1940-1957. doi: 10.1210/me.2007-0020

Wehbi, V., Decourtye, J., Piketty, V., Durand, G., Reiter, E., and Maurel, M. C. (2010a). Selective modulation of follicle-stimulating hormone signaling pathways with enhancing equine chorionic gonadotropin/antibody immune complexes. Endocrinology 151, 2788-2799. doi: 10.1210/en.2009-0892

Wehbi, V., Tranchant, T., Durand, G., Musnier, A., Decourtye, J., Piketty, V., et al. (2010b). Partially deglycosylated equine LH preferentially activates beta-arrestin-dependent signaling at the follicle-stimulating hormone receptor. Mol. Endocrinol. 24, 561-573. doi: 10.1210/me.2009-0347

Wightman, B., Ha, I., and Ruvkun, G. (1993). Posttranscriptional regulation of the heterochronic gene lin-14 by lin- 4 mediates temporal pattern formation in $C$. elegans. Cell 75, 855-862. doi: 10.1016/0092-8674(93)90530-4

Wu, Q., Song, R., Ortogero, N., Zheng, H., Evanoff, R., Small, C. L., et al. (2012). The RNase III enzyme DROSHA is essential for microRNA production 
and spermatogenesis. J. Biol. Chem. 287, 25173-25190. doi: 10.1074/jbc.M112. 362053

Xiao, K., McClatchy, D. B., Shukla, A. K., Zhao, Y., Chen, M., Shenoy, S. K., et al. (2007). Functional specialization of beta-arrestin interactions revealed by proteomic analysis. Proc. Natl. Acad. Sci. U.S.A. 104, 12011-12016. doi: 10.1073/ pnas. 0704849104

Xiao, K., Sun, J., Kim, J., Rajagopal, S., Zhai, B., Villen, J., et al. (2010). Global phosphorylation analysis of beta-arrestin-mediated signaling downstream of a seven transmembrane receptor (7TMR). Proc. Natl. Acad. Sci. U.S.A. 107, 15299-15304. doi: 10.1073/pnas.1008461107

Yamashita, Y. M., Jones, D. L., and Fuller, M. T. (2003). Orientation of asymmetric stem cell division by the APC tumor suppressor and centrosome. Science 301, 1547-1550. doi: 10.1126/science.1087795

Yan, N., Lu, Y., Sun, H., Tao, D., Zhang, S., Liu, W., et al. (2007). A microarray for microRNA profiling in mouse testis tissues. Reproduction 134, 73-79. doi: 10.1530/REP-07-0056

Yang, L., Chen, D., Duan, R., Xia, L., Wang, J., Qurashi, A., et al. (2007). Argonaute 1 regulates the fate of germline stem cells in Drosophila. Development 134, 4265-4272. doi: 10.1242/dev.009159

Yang, P., and Roy, S. K. (2006). A novel mechanism of FSH regulation of DNA synthesis in the granulosa cells of hamster preantral follicles: involvement of a protein kinase C-mediated MAP kinase 3/1 self-activation loop. Biol. Reprod. 75, 149-157. doi: 10.1095/biolreprod.105.050153

Yao, G., Liang, M., Liang, N., Yin, M., Lu, M., Lian, J., et al. (2013). MicroRNA224 is involved in the regulation of mouse cumulus expansion by targeting Ptx3. Mol. Cell. Endocrinol. 382, 244-253. doi: 10.1016/j.mce.2013. 10.014

Yao, N., Lu, C. L., Zhao, J. J., Xia, H. F., Sun, D. G., Shi, X. Q., et al. (2009). A network of miRNAs expressed in the ovary are regulated by FSH. Front. Biosci. 14, 3239-3245. doi: $10.2741 / 3447$
Yao, N., Yang, B. Q., Liu, Y., Tan, X. Y., Lu, C. L., Yuan, X. H., et al. (2010). Follicle-stimulating hormone regulation of microRNA expression on progesterone production in cultured rat granulosa cells. Endocrine 38, 158-166. doi: 10.1007/s12020-010-9345-1

Zeleznik, A. J., Saxena, D., and Little-Ihrig, L. (2003). Protein kinase B is obligatory for follicle-stimulating hormone-induced granulosa cell differentiation. Endocrinology 144, 3985-3994. doi: 10.1210/en.2003-0293

Zhang, Q., Bhola, N. E., Lui, V. W., Siwak, D. R., Thomas, S. M., Gubish, C. T., et al. (2007). Antitumor mechanisms of combined gastrin-releasing peptide receptor and epidermal growth factor receptor targeting in head and neck cancer. Mol. Cancer Ther. 6, 1414-1424. doi: 10.1158/1535-7163.MCT-06-0678

Conflict of Interest Statement: The authors declare that the research was conducted in the absence of any commercial or financial relationships that could be construed as a potential conflict of interest.

Received: 15 November 2013; paper pending published: 29 November 2013; accepted: 12 December 2013; published online: 27 December 2013.

Citation: León K, Gallay N, Poupon A, Reiter E, Dalbies-Tran R and Crepieux $P$ (2013) Integrating microRNAs into the complexity of gonadotropin signaling networks. Front. Cell Dev. Biol. 1:3. doi: 10.3389/fcell.2013.00003

This article was submitted to Cellular Endocrinology, a section of the journal Frontiers in Cell and Developmental Biology.

Copyright () 2013 León, Gallay, Poupon, Reiter, Dalbies-Tran and Crepieux. This is an open-access article distributed under the terms of the Creative Commons Attribution License (CC BY). The use, distribution or reproduction in other forums is permitted, provided the original author(s) or licensor are credited and that the original publication in this journal is cited, in accordance with accepted academic practice. No use, distribution or reproduction is permitted which does not comply with these terms. 